Kingsley, Morley, Das, Mayan, \& Wallace (2021)

\title{
ANSERJ
}

Vol. 12, No. S1

Autumn / automne 2021

pp. $46-64$

Canadian Journal of Nonprofit and Social Economy Research

Revue canadienne de recherche sur les OSBL et l'économie sociale

\section{Attempting to Address Conditions of Poverty through an Inclusive Economic Approach in Alberta}

\author{
Bethan Kingsley, Kirstyn Morley, Surma Das, Maria Mayan, \& Emma Wallace \\ University of Alberta
}

\begin{abstract}
This article responds to the call to alter current economic and social systems in light of COVID-19 by documenting initial efforts by a community-university partnership to build an inclusive economy. First, the effects of neoliberalism and oil extraction are examined to highlight the inequality that existed in Alberta long before the pandemic began. The paper then outlines four key areas of change: employment and training; social procurement and community benefits agreements; living wages; and basic income. It concludes with some initial learnings that may have resonance for others attempting to stimulate economic practices that distribute wealth more equitably.
\end{abstract}

\section{RÉSUMÉ}

Cet article répond à un désir de modifier les systèmes économiques et sociaux actuels en conséquence du COVID-19. Il le fait en décrivant des efforts préliminaires de la part d'un partenariat communauté/université pour établir une économie qui soit plus inclusive. L'article examine d'abord les conséquences du néolibéralisme et de l'extraction du pétrole afin de souligner les inégalités qui existaient déjà en Alberta bien avant le début de la pandémie. L'article présente ensuite quatre domaines clés qu'on aurait besoin de modifier : l'emploi et la formation; les ententes sur l'approvisionnement social et sur les avantages communautaires; le salaire de subsistance; et le revenu de base. L'article conclut en faisant des observations préliminaires qui pourrait inspirer d'autres individus tentant d'encourager des pratiques économiques orientées vers une distribution plus équitable de la richesse.

Keywords / Mots clés : Poverty; Precarity; Inequality; Inclusivity; Economy / Pauvreté; Précarité; Inégalité; Inclusivité; Économie

\section{INTRODUCTION}

The COVID-19 pandemic has drastically reshaped economic and social realities across Canada and further highlighted the inadequacy of existing economic and social systems to protect against poverty (Findlay, Saulnier, \& Stratford, 2020). Early into the pandemic, Jorge Sousa and Marco Alberio (2020) called for deep reflection to consider the ways we can learn from the experiences of the pandemic and build new structures and practices that transcend the status quo. In light of this call, this article examines and critiques initial efforts to create an inclusive economy through a community-university partnership comprised of researchers and practitioners working in the area of poverty reduction. Specifically, the part- 


\section{Kingsley, Morley, Das, Mayan, \& Wallace (2021)}

nership sought to respond to the question, "to what extent might the creation of an inclusive economy be possible as a way to mitigate precarity and poverty?"

This article first situates the work by describing the community-university partnership, and then outlines Alberta's economic and social context-prior to and since the start of the pandemic - with a particular focus on neoliberalism, petroculture, and the role they both play in exacerbating conditions of inequality and poverty. It then broadly outlines the concept of an inclusive economy, and the ways the partnership is attempting to create one in Edmonton. Finally, it discusses some of the challenges experienced in the early stages of this work in the hopes it can support others attempting to shape economic recovery and address the underlying systems and politics that have led us here.

\section{COMMUNITY-UNIVERSITY PARTNERSHIP}

The community-university partnership involves a collaboration between EndPovertyEdmonton and the CommunityUniversity Partnership for the Study of Children, Youth, and Families (CUP). EndPovertyEdmonton is a community-wide initiative working to eliminate poverty in Edmonton by tackling the root causes, including shifting dominant societal values about poverty's causes and solutions. The initiative was created by a taskforce involving stakeholders from funding agencies, universities (including one of the authors on this article), nonprofit organizations, and municipal government, all with an interest in addressing poverty. The mayor of Edmonton also endorsed the taskforce and EndPovertyEdmonton, and the City of Edmonton has been a primary funder and strategic partner of EndPovertyEdmonton since its development, with ongoing representation on the steering committee and other advisory committees. Through these close partnerships with the municipality and other community organizations, EndPovertyEdmonton's work is organized around six "game changers": liveable incomes, affordable housing, accessible and affordable transit, affordable and quality childcare, access to mental health services, and eliminating racism. To mobilize efforts in these areas, EndPovertyEdmonton operates as a convening entity, intended to increase investment in poverty elimination, mobilize collective efforts, and advocate for policy and systems change.

During an intensive strategic planning process conducted in early 2020, just as the effects of the COVID-19 crisis were becoming more obvious, EndPovertyEdmonton identified liveable incomes as a priority area. This decision was made in the recognition that having a sufficient income-whether via a living wage through employment or reliable social security-is essential for meeting basic needs and accessing services, such as quality childcare, housing, and transit, that can provide an exit out of poverty. Work within the liveable incomes priority area aims to ensure that all residents of Edmonton have basic financial security that facilitates participation in the community and supports peoples' dignity (Edmonton Social Planning Council, 2019a). This shift in prioritization gained the support of municipal, community-based, and funding partners who sit on the steering committee. The City of Edmonton has been working closely with the staff of EndPovertyEdmonton, particularly in the area of social procurement, to better understand how procurement policies can be implemented to support equity.

Research is a core aspect of the partnership's work, as it helps to situate practice-based efforts within a broader knowledge context. As such, research informs decision-making in the development of strategies and initiatives by drawing on lessons learned elsewhere and asking questions locally. EndPovertyEdmonton's research is supported by partners at CUP, a research entity at the University of Alberta that uses a community-based research approach to generate mutually beneficial knowledge in collaboration with stakeholders from community agencies, governments, and funding agencies (Israel, Eng, Shulz, \& Parker, 2013; Minkler \& Wallerstein, 2018). CUP has been involved in poverty-related research since 2001 and was present at the decision-making tables in the creation of EndPovertyEdmonton in 2012. Since this time, CUP has worked directly in partnership with EndPovertyEdmonton to inform poverty-reduction efforts in Edmonton. This has created a foundation for the current collaborative work in the creation of an inclusive economy. 


\section{THE CASE FOR A NEW ECONOMIC APPROACH}

The following section describes the Alberta context to situate the specific need for an inclusive economy in Edmonton. It also shows how these provincial influences unfold in a municipality to facilitate or limit potential opportunities for creating an inclusive economy at the local level. Although this work is situated in Alberta, it has relevance to provinces and municipalities across Canada because the conditions that give rise to the need for an inclusive economic approach are prevalent across jurisdictions, even as they present in unique ways in different contexts. What occurs in Alberta is inextricably connected to the rest of Canada (Shrivastava, 2015), with local histories offering a great deal of insight into the patterns and tendencies of a broader society.

Neoliberalism is first discussed as an ideology that rapidly gained traction over the last several decades and has become formidable, not only in Canada but globally. This is followed by a look at the effects of a dominant petroculture in Alberta (and Canada), which is intricately tied to neoliberal ideology in ways that perpetuate and exacerbate economic and social inequalities at the local level. It is important to highlight here that as a settler colonial state, Canada is founded on the dispossession and displacement of Indigenous peoples (Tomiak, 2017). A full analysis of colonization is outside the scope of this article, but it must be understood as the basis for both the past and current state of capitalism in Canada and, therefore, as inextricably connected to neoliberalism and oil extraction in Alberta (McCormack \& Gordon, 2020; Preston, 2017).

\section{Neoliberalism}

This section provides a brief overview of neoliberalism and its effects over previous decades to illustrate the already weakened social systems that existed before COVID-19, which has resulted in intensifying economic precarity for many (Hillel, 2020).

\section{Neoliberal politics}

Neoliberalism is generally considered a political and social era that began in the late 1970s and early 1980 s and continues in full force today (Cummins, 2018; Keil, 2002). First introduced by Ronald Reagan and Margaret Thatcher in the United States and United Kingdom, respectively, neoliberal politics have since been widely adopted by Western governments around the world, including in Canada (Keil, 2002). Defined by Wendy Larner (2006) as a set of policies, ideologies, and governmentalities, neoliberalism arose in opposition to more interventionist approaches that followed World War II, such as Keynesian economic policies. Keynesian economics, and other similar interventionist approaches, sought to redistribute wealth, reduce inequality, and protect the most vulnerable Canadians (Navarro, 1998), though it is important to recognize that many racialized individuals were still excluded from this category of "Canadian," even during the welfare state era (Thobani, 2007; Wacquant, 2009).

At its core, neoliberalism is characterized by the belief that state intervention undermines economic and social development (Navarro, 1998). Neoliberal policies, therefore, purport to improve the efficiency of economies through government downsizing and "deregulation" while supporting substantial government intervention (Hallstrom, 2018). Further, neoliberalism seeks to expand competitive market forces into new areas, leading to the "marketization" (and privatization) of public services under a mantra of choice (Cummins, 2018).

\section{Austerity measures}

Within this free-market ideology, public deficits are viewed as inherently negative (Navarro, 1998). Neoliberal governments thereby rely on austerity measures and financial cuts to reduce budget deficits, which serves to erode the welfare state while simultaneously delegating responsibility for social services to nonprofit organizations (Navarro, 1998). In Alberta, neoliberal efforts were introduced most fervently during the Ralph Klein era in the 1990s with a drive to "balance the budget" and address Alberta's "spending problem"; rhetoric introduced to justify policy decisions (Brownsey, 2018). Among a range of social and cultural impacts, Klein's neoliberal politics led to defunding kindergarten education, closing hospitals, 


\section{Kingsley, Morley, Das, Mayan, \& Wallace (2021)}

cutting social assistance and social programs and tightening eligibility requirements, privatizing public services, reducing corporate taxes, and replacing a progressive tax with a 10 percent flat tax (Brownsey, 2018; Shrivastava \& Stefanick, 2015). In Edmonton, the human services sector has felt the effects of these austerity measures, with nonprofit organizations expected to address increasingly compounded problems with fewer resources and limited staff capacity (Edmonton Chamber of Voluntary Organizations, 2016). Further, as these organizations are largely reliant on government funding, a significant portion of their limited resources are spent applying for and administering grants at the expense of front-line services (Harrison \& Weber, 2015). This dependence on government funding also means that nonprofit organizations in Edmonton have less flexibility to respond to community needs and are compelled to provide services in ways that align with government mandates (Edmonton Chamber of Voluntary Organizations, 2021).

\section{Personal responsibility}

In addition to weakening economic and social security structures, neoliberal governance has fostered and perpetuated an ideology that advocates personal responsibility. Individuals living in poverty come to be blamed for their own material circumstances (Cummins, 2018; Dixon, 2012). Loïc Wacquant (2009) has referred to such policies as "neo-Darwinist" (p. 5) in the ways they serve to promote societal competition and individualism. This individualistic and meritocratic culture is pervasive in Alberta (Hallstrom, 2018) and serves to perpetuate the fallacy of the self-sufficient, hard-working, and independent individual while stigmatizing and "othering" those who cannot succeed under such circumstances due to structural barriers (Cummins, 2018; Dixon, 2012). In Edmonton, discourses such as these create significant barriers to poverty-reduction work. With a widespread perception that employment and wealth are readily available in an oil-rich province, many people believe poverty does not exist in the city or that those living in poverty are to blame for their own circumstances (City of Edmonton, 2019). Not only must poverty reduction efforts in Edmonton seek to address structural barriers such as affordable housing and food insecurity, resources must also be allocated to shifting public consciousness around the need to invest in this area (EndPovertyEdmonton, 2020). The continued dominance of neoliberalism in Alberta is also further complicated by the presence of and reliance on bitumen oil as a central economic (and, therefore, political, social, and cultural) force.

\section{Petroculture}

While the first major natural gas discovery in Alberta was made in 1908, it was the 1947 discovery of oil in Leduc, a small municipality outside of Edmonton, that would transform Alberta's economic future. This discovery led to rapid urbanization, economic growth, and a substantial increase in the province's population (Fraser, Mannani, \& Stefanick, 2015). Since then, Alberta's economy has become almost entirely dependent on oil and gas, which account for 70 percent of the province's exports (Shrivastava, 2015). Although Alberta's economy has always been based on a single, dominant commodity (e.g., wheat, beef), the ubiquitous demand for oil has resulted in its suppliers having an excessive amount of power in both the market and political sphere (Shrivastava \& Stefanick, 2015).

\section{Economic, political, social, and cultural life}

As with neoliberalism, the presence of oil in Alberta is not simply a matter of economics. Oil and non-renewable energy production are part of a larger petroculture that shapes the economic, political, social, and cultural life of the province and the cities within it (Shrivastava, 2018). Not only does the oil industry play a substantial role in Alberta's politics, directly and indirectly (Foster \& Barneston, 2015), many Albertans identify so strongly with oil they believe it inherent to their well-being (Harrison, 2015). This has largely protected the oil industry from external and internal criticism, and it has allowed oil companies an inordinate amount of power (Shrivastava \& Stefanick, 2015). Combined with a largely uninterrupted conservative party rule for more than 80 years, along with entrenched neoliberal politics in the last several decades, this has resulted in Alberta becoming a right-wing corporatist state through which there is little to distinguish the interests of governments from those of private corporations (Harrison, 2015; Shrivastava \& Stefanick, 2015). 


\section{Kingsley, Morley, Das, Mayan, \& Wallace (2021)}

Economic and social inequalities

Alberta's economic dependence on oil is of particular significance because it interconnects and overlaps with neoliberal ideology to perpetuate and exacerbate economic and social inequalities. Although Alberta stands as one of the wealthiest provinces in Canada, this wealth is not equally distributed. As such, Alberta has the highest rates of inequality of any Canadian province, with the wealthiest one percent drawing incomes over 46 times those of the poorest ten percent (Flanagan, 2015; Graff McRae, 2017). Income inequality is also high in Edmonton. Between 1982 and 2017, the top 0.1 percent of tax filers saw a 56.8 percent increase in income, while the bottom 50 percent only saw an increase of 3.2 percent (Edmonton Community Foundation, 2021). This inequality has been produced and exacerbated by deregulation (in favour of industry), privatization, the lowering of taxes, and cuts to government programs (Harrison, 2015). Although such practices are indicative of neoliberal governance and are evident in many countries around the world, the notable shrinking of redistributive policies and programs in Canada has arguably been accelerated by the country's rise as a global exporter of oil (Shrivastava, 2018). Indeed, income inequality has increased at a faster pace in Canada than in many other countries in the last several decades (Shrivastava, 2018). This has obvious and direct consequences for urban centres in Alberta, including Edmonton, which reside at the epicentre of this oil production.

As the main site of petroleum extraction, the scaling back of redistributive programs and policies in Alberta has been acute (Fraser et al., 2015). Among a range of consequences, the prominence of oil has led to the diminished influence of unions alongside significant encroachments on workers' wages, benefits, and rights (Barnetson, 2015; Shrivastava \& Stefanick, 2015). Although these concessions have dire outcomes for all residents, they have particularly damaging outcomes for women and racialized people who are overrepresented in low-paying jobs, underemployment, and unemployment (Fraser et al., 2015; Russek, Thornton, \& Elias, 2021).

This inequality is also inextricably connected to the neoconservative ideology of the province, which holds the heteropatriarchal family structure as the ideal and reinforces heteropatriarchal norms, laws, and political institutions (Fraser et al., 2015). As such, most high-paying positions are filled by white men, and the responsibility of unpaid and low-paid labour falls predominantly on women, many of whom are racialized (Dorow, 2015). Women's participation in the labour force is further undermined by a lack of political prioritization for adequate childcare, parental leave, and infrastructure essential for employment, such as public transportation (Lahey, 2015).

\section{Economic instability}

Although these inequalities are pervasive when oil prices are high and there is an abundance of available wealth in the province, they are especially pronounced during periods of recession. Alberta's reliance on oil as a single commodity leaves the province's municipalities vulnerable to volatile external markets and creates a cyclical boom and bust economy (Emery \& Kneebone, 2013). The effects of this economic instability on people living with precarity and the consequences for the human services sector in Edmonton are notable. Economic "booms" lead to population increases, housing shortages, high rents, and stress on existing infrastructure while economic "busts" are marked by funding shortfalls at the exact time that demand for services increases (Edmonton Chamber of Voluntary Organizations, 2016).

This instability and its effects can be seen with each and every recession. After decades of expanding the oil industry to maximize profits, a global recession in the 1980s caused oil prices to crash with significant damage to Alberta's economy. This led to substantial unemployment across the province, housing foreclosures, and widespread food insecurity (Harrison, 2015). Although Alberta's economy eventually recovered, it remained vulnerable to-and, some would argue, became even more reliant on-unpredictable external markets due to a combination of escalated extraction and the increasing costs of oil production. As such, Alberta experienced recessions in 2008 and 2014, with similarly devastating effects 
(Shrivastava \& Stefanick, 2015). Alberta, and Edmonton, had not yet recovered from this latest downturn in oil prices when the COVID-19 pandemic led to a social and economic lockdown in March 2020.

\section{The COVID-19 pandemic}

Although it can be argued that the inadequacies of societal systems were abundantly apparent before COVID-19, supported by willful ignorance rather than a lack of visibility, the pandemic has undisputedly changed and exposed the economic and social landscape of our societies in unprecedented ways (Findlay, Saulnier, \& Stratford, 2020). Specifically, the COVID-19 pandemic has added distinct pressure on the economy, with Canada reaching a record-high unemployment rate of 13.7 percent in May 2020 (Statistics Canada, 2020d). From February to April 2020, 3 million Canadians experienced job disruptions, and another 2.5 million worked less than half of their typical hours (Statistics Canada, 2020c). Further, the dual shocks of the pandemic and volatility in the oil and gas sector has signalled a prolonged economic downturn in Alberta, where reliance on a single commodity has led to decreased resilience. In January 2021, Alberta's unemployment rate ranked as the second highest in Canada, with Edmonton's unemployment rate among the highest of major Canadian cities (Statistics Canada, 2021). In March and April 2020, employment in low-wage jobs dropped by 38 percent across Canada, compared with just 13 percent for all other jobs (Statistics Canada, 2020d). From February to April 2020, over half of all workers in the lowest wage bracket (earning less than $\$ 16$ per hour) lost most or all of their work; this was the case for just one percent of workers in the highest-wage decile (earning $\$ 48 / h$ or more; Stanford, 2020).

The pandemic's effects on employment have, unsurprisingly, been both gendered and racialized (Statistics Canada, 2020c; van Barneveld, Quinlan, Kriesler, Junor, Baum, Chowdhury, Junankar, Clibborn, Flanagan, Wright, Friel, Halvie, \& Rainnie, 2020). For example, women have experienced greater job losses and slower employment gains than men due to a disproportionate loss of jobs in feminized sectors (e.g., retail, hospitality, food services), the overrepresentation of women in low-paid and part-time work, and women's roles in unpaid care work (Goertzen, 2020; Statistics Canada, 2020b). From August to December 2020, unemployment rates among Indigenous (13\%), Black (13\%), and other racialized Canadians (11.5\%) was far higher than for white Canadians $(7.4 \%)$, in part due to the prevalence of racialized workers in the hard-hit service sector (Block, 2021).

These significant job losses as a result of COVID-19 have caused many in Edmonton to experience material deprivation in ways they may not have previously, with an increase in the number of people experiencing precarity and conditions of poverty. In response to the dire circumstances being faced by many individuals and families in the city, local organizations and municipal government agencies have come together to try to find collective solutions to the crises arising from the pandemic. For example, a food insecurity table was created by the municipal government shortly after the pandemic began to orient nonprofits to the work of emergency food provision and to more effectively facilitate the collective distribution of resources. An existing partnership between the municipal government and local immigrant and newcomer-serving nonprofit organizations also redirected its efforts to better understand the issues that arose after the first lockdown and create crosssystem working groups to respond to the challenges, such as a lack of access to technology. The COVID-19 pandemic created a context in which collaborations and ways of working to address poverty and precarity that had not been previously desirable suddenly became both urgent and possible. As poverty elimination provides the underlying motivation for the partnership described here, the following section offers a brief overview of poverty in Edmonton.

\section{Poverty in Edmonton}

Poverty is generally considered to be the condition of being deprived of the "resources, means, choices and power necessary to acquire and maintain a basic level of living standards and to facilitate integration and participation in society" (Canada, 2018, p. 8). Despite this broad definition, poverty is generally measured according to available income, since this is the easiest way to broadly estimate how many people experience conditions of poverty (although this process is 
not without its complications, as the multiple methods of measuring poverty in Canada attest). In 2018, the Canadian government announced its first poverty reduction strategy, Opportunity for All, and adopted the Market Basket Measure (MBM) as Canada's official measure of poverty, based on the cost of a suite of goods and services representing a basic standard of living (Statistics Canada, 2016). Other Canadian municipalities, including Edmonton have followed the federal government's lead and adopted the MBM. Using this measure, Edmonton's poverty rate in 2018 (the latest year for which data is available) was 7.5 percent (Statistics Canada, 2018). In terms of composition, women and children comprise a large majority, with close to 8,500 female-led, lone-parent households living with lower incomes in Edmonton and nearly one in five children experiencing poverty prior to the pandemic (Edmonton Social Planning Council, 2019a).

Employment is obviously a significant determinant in whether somebody experiences poverty. Employment in and of itself, however, is not enough to mitigate conditions of poverty. This is primarily because employment in Canada does not guarantee a living wage. Prior to COVID-19, 50-70 percent of Canadians living in poverty were employed, often holding multiple jobs (Jackson, 2018; Lefroncois, 2015). Alberta has one of the highest rates of working poverty in Canada (Edmonton Social Planning Council, 2017). In Edmonton, the living wage for a dual-income family of four in 2019 (the most recent year for which living wage was calculated) was $\$ 16.51$ per hour (Edmonton Social Planning Council, 2019b). With the minimum wage currently at $\$ 15$ per hour for adults and $\$ 13$ per hour for those under the age of 18 , many individuals living in Edmonton do not earn a wage sufficient to cover costs for themselves and their families. Further, even with living wage legislation in place, there is no guarantee workers will receive it. For example, over a 12-month period (between July 2017-2018), an average of 117,300 people employed in the Edmonton area earned less than the stipulated \$16.51 per hour wage (Edmonton Social Planning Council, 2020a). Low-wage employment is also connected to the broader issue of precarious work, which is a pervasive problem. Precarious jobs are characterized by instability and insecurity, and they have several common features, including low pay, part-time hours or irregular and unpredictable schedules, and few benefits or job protections (Lewchuk, Lafleche, Dyson, Goldring, Meisner, Procyk, Rosen, Shields, Viducis, \& Vrankulj, 2013). In the Edmonton region specifically, over three-quarters of jobs are in the services sector, which tend to be low-paying, precarious jobs (Edmonton Social Planning Council, 2017).

Having a sufficient and reliable income has obvious impacts for accessing nutritious food, safe and affordable housing, and other necessities. Prior to the pandemic, 13.8 percent of Edmonton residents were food insecure with a lack of access to quality food due to financial, physical, or social barriers (Edmonton Social Planning Council, 2020b). As many as one in five families in Edmonton were spending more than 30 percent of their income on housing prior to the pandemic (Edmonton Social Planning Council, 2019a). Many of these families also spent the equivalent or more on childcare costs (EndPovertyEdmonton, 2019), a necessary expense to maintain employment opportunities. Although no figures are yet available, work conducted through the partnership shows that the number of individuals and families experiencing hardship has increased substantially since the start of the pandemic. Within this context and with a mandate to address poverty in Edmonton, the partnership set out to explore strategies that could support an inclusive economy in Edmonton through a poverty reduction lens.

\section{TOWARD AN INCLUSIVE ECONOMY APPROACH}

This section outlines the inclusive economy concept before describing the specific strategies the community-university partnership is exploring in an attempt to address poverty in Edmonton through economic recovery efforts in response to COVID-19. Unfortunately, there is currently only minimal literature available that speaks to the concept or the attempted creation of inclusive economies (Lee, 2019). As such, this research draws on a wider range of literature that describes a variety of relational economic models (e.g., the social solidarity economy, the care economy) that seem to generally align with and support the underlying principles of an inclusive economy. 


\section{Kingsley, Morley, Das, Mayan, \& Wallace (2021)}

\section{Inclusive economies}

In light of the failings of dominant economic models, particularly following the economic crisis of 2008 and more recently COVID-19, newer relational economic models have begun to come to the fore in the Global North. As an alternative to individualistic, rational free-market economies (Chang, 2014), relational models intend to provide a more holistic framework for understanding the economy and provide a pathway toward achieving equitable outcomes.

\section{Relational models and equitable outcomes}

Relational economic models purport the value of mutuality and social connectedness; they acknowledge the interdependence that exists between the economy, society, and the environment (Raworth, 2017; van Osch, 2013). Although there are a number of terms to describe such approaches, inclusive economies is used here to articulate a relational economic approach that challenges the causes of income inequality to raise the standard of living for all individuals. As such, the focus of these models is on social rather than economic profit. With an emphasis on redistributive justice and deep sustainability, inclusive economy approaches prioritize social objectives and consider the collective value of producers, workers, consumers, and citizens (Utting, 2015). Further, they acknowledge and value the role of unpaid labour as essential to a thriving economy, which is of particular and growing importance in an aging society and one in which childcare is becoming less and less affordable (van Osch, 2013).

The concept of an inclusive economy provides an alternative framework for understanding the economy, with the goal of creating widespread economic prosperity for all members of a community. Specifically, an inclusive economy approach directly challenges the causes of poverty and income inequality to raise the standard of living for all individuals (Lee, 2019; Utting, 2015), whereby opportunities exist for all people to participate in the economy, there is an equitable distribution of the benefits and harms of economic activity, and there are opportunities for all people to participate in decisionmaking about the systems that affect them (Munro, 2002).

\section{The need for contextualized evidence}

Although some would consider an inclusive economy approach to be on the "radical" fringes of economic thought, the concept has attracted increasing attention in the mainstream since the 2008 global financial crisis (Utting, 2015). Despite this increased interest, there is relatively little evidence documenting attempts to develop and implement policies and practices that support an inclusive economy approach (Lee, 2019). As the inclusive economy concept originated in the late 2000s among the economic development community in the Global South (supplanting the concept of "pro-poor growth"), what little evidence that does exist about how economic policies can promote equity is largely specific to developing countries (Lee, 2019). Among developed countries, where an inclusive economy approach has only recently become popular among policymakers and (to a far lesser degree) researchers, the evidence base is even weaker. Most research in developed countries has focused on conceptual issues of defining and distinguishing terms associated with this approach (e.g., inclusive growth, growth plus, inclusive economy), as well as describing examples of innovative inclusive economy initiatives, generally in the absence of any accompanying research or evaluation evidence to suggest "what works" (Lupton, Hughes, Macdougall, Goldwyn-Simpkins, \& Hjelmskog, 2019). Without research investigating the outcomes of these policies for different groups, the inclusive economy rhetoric is at risk of being co-opted (intentionally or otherwise) to justify policies that may actually perpetuate the inequities this approach intends to mitigate (Lee, 2019). Indeed, an important criticism levelled at this concept is that "inclusive economy" has become a buzzword and used as window dressing to justify long-standing policies that uphold the status quo and do not lead to any meaningful, transformative change to existing systems (Lee, 2019).

Further, an inclusive economy approach is influenced by the unique economic, political, and institutional contexts of a particular community (Lupton et al., 2019) and is, therefore, place based. While trends such as rising inequality, the in- 
crease of precarious work, and labour market disruptions due to technology and energy transitions are consistent across other developed countries such as the United Kingdom and the United States (where most of the research about inclusive economies in developed countries originates), inclusive economy strategies must also be situated within the specific realities of a given community. There is a clear need not only for research in this area but for community-based research that builds a knowledge base that both informs and is informed by "on the ground" change efforts. With one of the highest income disparities in Canada, Edmonton provides both a necessary and interesting site of study within an Alberta petroculture context. As such, this partnership set out to explore possibilities for creating an inclusive economy in Edmonton to mitigate poverty.

\section{Inclusive economy efforts}

Environmental scan

Recognizing increasing attempts to create alternative economic models and strategies, whether or not they used the specific term inclusive economy, a member of the partnership conducted an environmental scan to get a sense of what existed locally and further afield that could inform local efforts. The scan involved a review of literature and informal interviews with a variety of stakeholders working in community-based organizations, industry, educational institutions, governments, and regional economic development organizations. The intention of the environmental scan was to learn about emerging and best practices in Edmonton and further afield, and gauge interest for collaborating locally. This resulted in a report (Hanewich, 2019) that outlined possible ideas for creating an inclusive economy relating to two core concepts: inclusive growth and workforce development. It also highlighted how essential it is to enable cross-sector collaboration in the pursuit of an inclusive economy, particularly between educational institutions, industry, government, and community organizations.

Ideally, educational institutions would provide education and training to create pathways into employment, working with employers to align training with industry needs, and creating policies to reduce financial barriers to education. Industry would play a role in supporting good working conditions (e.g., consistent schedules, living wages) for lower paying jobs, creating pathways from low- to higher-paying positions, and considering equity in hiring and training in sectors poised for growth. Governments would create targeted policies and programs (e.g., social procurement), directing regional priorities, and ensuring physical and social infrastructure exists to enable people to access economic opportunities (e.g., transportation, affordable housing, childcare, community services). Community organizations would provide workforce development supports, tailor training to workforce trends, and develop partnerships with employers who provide good jobs. And individuals who are economically marginalized, many of whom experience poverty, would be centred in economic discussions to develop new strategies that allow everyone to contribute to and benefit from the economy.

To collectively work toward an inclusive economy, training and education providers and community/nonprofit organizations need to coordinate their efforts with industry to ensure workforce development strategies are aligned with employment opportunities and reduce barriers to acquiring gainful work. Employers and industry must understand the role they play in creating good working conditions, supporting workers with stable schedules, living wages, and other factors that contribute to decent work. At an overarching level, regional economic development organizations must lead the way in setting transparent economic development strategies that are targeted to those living in poverty, supported by governments that foster an inclusive growth ecosystem through incentives and supports for all stakeholders. With this foundational knowledge and with an appreciation for the emergent nature of the work, the partnership has chosen to engage in extensive cross-sector and community collaboration over the next several years. In particular, it has recognized how important it will be to bring industry, community-based organizations, educational institutions, municipal government, and people with lived experience together to align and contextualize the work. As such, a considerable amount of time is spent convening a variety of people situated across the city to determine where possible opportunities might lie. 


\section{Kingsley, Morley, Das, Mayan, \& Wallace (2021)}

Research and evaluation

A number of research methods have been incorporated to document the process of creating an inclusive economy. One researcher is solely dedicated to working alongside EndPovertyEdmonton and using fieldwork methods, such as participant observation and interviews, to answer the overarching question: to what extent can an inclusive economy be built locally as a way to mitigate conditions of poverty? The researcher participates in all partner meetings to understand the work that is taking place and attends cross-sector meetings to observe how people are working together, how decisions are made, and what barriers and facilitators exist to the creation of an inclusive economy. The researcher also supports the EndPovertyEdmonton in-house evaluator to assess progress using a developmental evaluation approach. Developmental evaluation can assist individuals or collectives to develop social change initiatives in complex or uncertain environments by guiding adaptation to emergent and dynamic realities (Patton, 2016). As with most poverty-related initiatives, measuring progress is exceptionally difficult because of the complexity involved and generally requires a patchwork approach of methods rather than a discrete and linear design (Cabaj, Leviten-Reid, Vocisano, \& Rawlins, 2016). Rather than specific indicators or predetermined outcomes, it can be helpful to have principles to help measure progress. Although this design is emergent, a broad question that is helping to guide both the work and the evaluation is: who receives the benefits of this initiative and who bears the costs? (Munro, 2020). Zeroing in on the distribution of effects resulting from the strategies implemented in the creation of an inclusive economy makes it possible to ensure that the benefits and potential harms are equally distributed, with particular attention to age, gender, class, disability, race, and other intersecting identities. By documenting and assessing the work in this area, the research team can help to track the extent to which equity is a central factor in efforts to create an inclusive economy and mitigate conditions of poverty.

\section{Strategic areas}

EndPovertyEdmonton has chosen to focus on four key content areas within an inclusive economy framework that, if achieved, would collectively ensure a sufficient level of income for all residents, whether or not they are employed.

1. Employment and training: Equip people with the skills needed to enter the labour market and earn liveable incomes

2 Social procurement and community benefits agreements: Create jobs in partnership with industry, governments, and community organizations and develop new markets for social enterprises, co-operatives, and minority owned businesses.

3. A living wage: Ensure people are provided good jobs that involve, among a range of things, a living wage.

4. Basic income: Create policies that enable a reasonable standard of living for all residents in Edmonton, regardless of their ability to work in paid employment. The work related to employment and training is heavily tied to social procurement and community benefit agreements because the creation of employment opportunities is futile without a sufficient number of individuals to apply for them. As such, both are discussed collectively below.

In relation to employment, training, and social procurement, EndPovertyEdmonton has several activities currently taking place. One of these involves convening a social procurement coalition monthly to explore ways to work with governments and other institutions to develop and implement sustainable procurement policies. The coalition comprises representatives from municipal government, city council, industry, trade union groups, and nonprofit organizations that support economic development. As a result of this work, social procurement policies are in the process of being developed through collaborations with the Alberta government, local universities, and Alberta Health Services, the biggest anchor institution in the province. As part of the City of Edmonton social procurement policy, EndPovertyEdmonton will work with the city to monitor the outcomes of social procurement projects and their impacts on the community. EndPovertyEdmonton has 


\section{Kingsley, Morley, Das, Mayan, \& Wallace (2021)}

also developed a process for working with developers bidding on infrastructure projects, such as transit development, guiding them to include equitable policies and practices with regards to hiring, training, and living wages.

Furthermore, EndPovertyEdmonton convenes a workforce development collaboration that involves professionals from a range of poverty and newcomer-focused nonprofit organizations, agencies that support employment and training, municipal government, and employers. The collaboration meets monthly to discuss potential employment and training opportunities for people who experience disproportionate unemployment and underemployment. Through the group, alignments are made between employers and agencies who support individuals in seeking employment and training, and efforts are made to remove and reduce barriers that may impede employment.

In addition to ensuring living wages through social procurement and community benefit agreements, EndPovertyEdmonton has also held and captured conversations with a wide number of business owners and employers to understand their practices and motivations for a living wage in order to increase understanding about how to incentivize the provision of adequate wages. These conversations also intended to see if there would be interest in creating an advisory committee to more deeply engage business owners and industry stakeholders in the process of creating an inclusive economy. One of the themes that has come from this work is the recognition that paying a living wage leads to better employee retention. These conversations also showed, however, a level of conservativism from many business owners and industry stakeholders and a desire to return to the pre-pandemic status quo, with a limited understanding that poverty and precarity are areas requiring attention in Edmonton and, more broadly, Alberta. As such, the motivation to create a business advisory committee to inform the creation of an inclusive economy has been fairly low and, unless it is carefully constructed, would have conflicting priorities that could ultimately undermine efforts to address poverty. As such, the creation of this advisory committee has been put on hold and EndPovertyEdmonton will continue to connect with individuals in business and industry to try and find a group of potential partners motivated to support inclusive economic outcomes. These conversations will also be used as a stepping stone to further examine the concept of good work; what it means to people and what can be done to improve workplace policies and practices. Further, EndPovertyEdmonton works closely with the Alberta Living Wage Council to inform living wage strategies across the province, including the development of a living wage employer accreditation process.

Finally, efforts to secure a basic income have mostly centred around advocacy. Advocating for basic income was not an area that initially received much attention because although the benefits to poverty reduction were clear, the introduction of such a policy felt politically elusive. Quite quickly after the COVID-19 pandemic began, however, a policy window seemed to open up in response to dramatic increases in food insecurity and the rapid implementation and distribution of government subsidies in Canada. At this time, there were a substantial number of calls for a basic income, including from EndPovertyEdmonton, which mobilized and sought the support of city councillors, politicians, business associations, labour groups, and others in the province. Work was also done to understand public perceptions of basic income in an attempt to raise consciousness about the benefits of a basic income policy. Since September 2020, the momentum around basic income seems to have slowed, but EndPovertyEdmonton continues to participate in provincial and federal advocacy discussions and is prepared to respond quickly if and when a new policy window opens up.

\section{DISCUSSION}

As this collective effort is only in the initial stages, it is too early to determine the successes and challenges of attempting to create an inclusive economy. Some initial areas of learning, however, are important to highlight for further discussion. The first relates to the extent to which a municipality is in a position to create its own inclusive economy. The second regards the balance between idealism and pragmatism, and the question of whether something is better than nothing at all. 


\section{Kingsley, Morley, Das, Mayan, \& Wallace (2021)}

\section{Cities as sites of transformation}

Cities are increasingly taking the lead in addressing a wide range of social, economic, cultural, and environmental problems. As inclusive economy strategies are place based and influenced by the unique economic, political, and institutional contexts of a particular community, municipalities might be best positioned to support the creation of inclusive economies. Inclusive economy strategies are inherently complex; they require the coordination of stakeholders who often hold divergent goals, priorities, and motivations. Municipal governments are uniquely situated to coordinate policy agendas across multiple orders and stakeholders (Lee, 2019), although this is far from easy to accomplish in practice.

Local governments also have the potential to directly support the implementation of inclusive economy strategies through spending on programs and services (e.g., skills training) and providing incentives to other stakeholders to implement similar strategies (e.g., providing business incentives to hire individuals with barriers to employment; Hanewich, 2019). As the level of government closest to citizens, municipal governments should have the greatest understanding of the realities of poverty in their communities and the strongest connections with local stakeholders while also playing a major role in influencing provincial and federal levels of government (Association of Municipalities of Ontario \& Ontario Municipal Social Services Association, 2009; Federation of Canadian Municipalities, 2017). Focusing on the city level makes it possible to tailor strategies to the needs, opportunities, and resources of a specific context. Similarly, data generated at a local level has the potential to build a more informed understanding of how the benefits and harms of economic strategies are being distributed among groups—as well as the unanticipated consequences of well-intentioned strategies—making it possible to ensure policies are truly inclusive and equitable (Lee, 2019; Munro, 2020). Because of the proximity between EndPovertyEdmonton and the City of Edmonton and the ways they work in close partnership, the municipality is kept up to date about poverty in the city and made aware of points of potential intervention. This has led to some policy changes and the development of programs such as subsidized public transit and a living wage policy for all municipal staff and contracted services. EndPovertyEdmonton's close, long-standing relationships with stakeholders across different sectors in Edmonton enables it to more easily convene groups at a local level and produce tangible outcomes that may be difficult at a provincial or federal level.

Despite all of us these advantages, the extent to which an inclusive economy can feasibly be built at the municipal level, without provincial and federal alignment and support, remains an unanswered but pertinent question. Some have raised doubts about the extent to which municipalities can shape inclusive economies at all given their limited powers and resources (Lee, 2019). Although there are certainly provincial differences in the ways municipalities are considered and treated, there is a general consensus that municipalities possess only a weak level of decision-making power legally and practically (Hallstrom, 2018). This can be seen clearly in the case of basic income, which requires policy changes at the federal level. With only a distal influence, this has limited efforts in this area. Subsequently, the partnership has primarily focused on advocacy and networking with other basic income groups across the province.

Beyond a lack of influence in policymaking, others have documented the ways municipalities have been too lenient in areas in which they do have the power to shape the urban economy and poverty reduction efforts. For example, a number of authors have criticized the role of municipalities in negotiating with business owners during the creation of community benefits agreements in development projects, citing a lack of accountability (e.g., Nugent, 2017; Parks \& Warren, 2009). Beyond a missed opportunity for achieving inclusive economic aims, such as the creation of employment opportunities with living wages, weak community benefits agreements run the risk of appearing progressive while, in reality, contributing to the gentrification of marginalized neighbourhoods (Gross, 2008; Nugent, 2017). In Edmonton, this was clearly seen in the development of a new ice hockey arena that was completed in 2016. During negotiations, the developer repeatedly threatened to take the franchise to a different city and the municipality repeatedly conceded to their demands (Scherer, Mills, \& Sloan McCulloch, 2019). As a result, the social benefits that could have been gained in the development of a 


\section{Kingsley, Morley, Das, Mayan, \& Wallace (2021)}

new stadium and surrounding area were entirely missed and many social harms accrued. Further, the conservative cost to the public has been estimated at \$1.5 billion; funds that could have been allocated elsewhere (Scherer et al., 2019).

The matter of what is possible in the creation of an inclusive economy at the municipal level is also particularly relevant for people living in Alberta, where the provincial government swung from the left-of-centre New Democratic Party to the far-right United Conservative Party (UCP) led by Jason Kenney. Since the UCP's election in April 2019, the provincial government has quickly moved to eradicate existing policies and introduce sweeping cuts, alongside familiar neoliberal promises to "balance the budget" and "cut red tape." Among a range of political moves, the UCP government has made significant investments in the oil industry, attempted to expand coal mining in the Rocky Mountains, introduced a \$30million-per-year energy information "war room," and made catastrophic cuts to institutions and services, particularly postsecondary education (Adkin, 2020; Markusoff, 2021). In such a political climate, the need for municipal agency and power to support an inclusive economy is clear. As long as municipalities remain "creatures of provinces" within Canada's constitutional system, however, they will struggle to exercise such autonomy (Keil, 2002). Creating an inclusive economy in Edmonton will therefore be especially difficult while such a strained political climate exists in Alberta.

\section{Pragmatic ideals}

A second dilemma in this work relates to balancing the desire for an inclusive economy with what is pragmatically possible. For society to move toward an inclusive economy—one that redistributes wealth more equitably, centres individuals who are economically marginalized in economic discussions and decision-making, and reconsiders value beyond capital accumulation-it will require a considerable and widespread desire for deep structural change. It will require sweeping policy adjustments and legislation that values and protects those who work and those who may never earn a full income through employment. It will also require a serious reassessment of our attachment to (settler colonial) neoliberal ideology and everything that derives from and intersects with it.

With this in mind, it is often difficult to know where to begin. Although more and more people are beginning to discuss the need for relational, redistributive economic models in opposition to the current state (e.g., Raworth, 2017; Utting, 2015; van Osch, 2013), these conversations tend to reside at the conceptual level. As such, there is limited practical guidance for how to build these economies in a comprehensive way to make significant and meaningful structural change. This limited guidance has been difficult for a partnership aiming to developing a strategy that can force actual structural change in the fight against poverty and not just add further window dressing to justify austerity measures (Lee, 2019). There is always the risk that initiatives introduced to change the current state actually serve to reinforce it (Nugent, 2017). As Audre Lorde (1984) reminded us, "the master's tools will never dismantle the master's house. They may allow us temporarily to beat him at his own game, but they will never enable us to bring about genuine change" (p. 112). Edmonton has indeed been criticized previously for taking a harm reduction approach (e.g., by improving services) rather than addressing the structural roots of poverty, such as the inequitable distribution of income and wealth (Raphael, 2020). In a city and province where oil is the primary economic driver and where white male conservatism prevails, it is extremely difficult to know whether, how, and when to push for more radical, structural change and when to leverage the opportunities that might be more feasible but might not achieve equitable structural outcomes (Nugent, 2017). In the area of social procurement, for example, the employment opportunities have tended to be in the construction industry and will, therefore, primarily benefit white men who were previously employed in the oil industry. These opportunities serve those who are more likely to make their way back into employment and do not support the larger majority of racialized women who have lost work in the service sector as a result of the economic downturn. There is a long way to go before we can build strategies that lead to actual wealth redistribution, and the introduction of regulation similar to the living wage policy will be essential in these redistribution efforts (Raphael, 2020). 
In doing this work well, it is also vital to more effectively centre individuals who are economically marginalized in the creation of strategies and policies that affect them. The partnership has experienced challenges in developing the structures for this engagement and has worked primarily with government, postsecondary, nonprofit, trade union, and industry representatives rather than citizens. The process of creating a decision-making panel of people who experience conditions of poverty to inform the work was started, but the panel's involvement had to be postponed when the pandemic began due to barriers of internet access, time, and disrupted life circumstances. Although the plan is to reconvene this advisory panel, it will take some time to re-establish. Until then, the partnership will continue to work closely with nonprofit professionals who act as representatives for the individuals and families they work with and can contextualize and inform decisions made at the coalition tables. Although this is obviously no substitute for the involvement of individuals and families, it is reflective of the sector at present; that is, a broad desire to move toward more full and inclusive modes of engagement without yet being fully realized.

This leaves the question of whether something is better than nothing in working toward an inclusive economy. This question has plagued the nonprofit sector and the partnership's own work in the neoliberal era, when the cycle of providing siloed emergency services is increasingly common (Spade, 2015). This has both undermined the ability to collectively advocate for structural change and inadvertently relieved governments of their responsibility to provide protective legislation and sufficient social security (Evans, 2015; Riches, 2002). In attempts to build an inclusive economy, this might be the equivalent of creating (good) employment opportunities through social procurement and community benefit agreements without seeing accompanying changes to public regulation that would alter the structure of employment across Alberta and Canada. Advocacy efforts, alongside more practical and immediate measures, are needed to move toward an alternative and inclusive economic state.

\section{CONCLUSION}

This article sought to outline initial efforts to build a new, inclusive economic approach in a city in Western Canada through a community-university partnership. Although this work is particularly challenging given Alberta's historical and political context, current instability, particularly in light of the COVID-19 pandemic, makes the need for systemic changes ever more urgent. And while spaces for democratic debate continue to be squeezed and governments increasingly introduce policies without public consultation, new arenas for resistance, contestation, and change are being created (Keil, 2002; Miller, 2007; Shrivastava, 2015). Such resistance has been seen recently in response to the destructive measures introduced by the UCP government, such as the attempted expansion of coal extraction. Widespread public pressure resulted in a government reversal on a number of actions, including the reinstatement of policy to protect certain areas from openpit mining (Markusoff, 202). Such examples of collective resistance indicate there is the potential to create economic policies, practices, and discourses in Alberta that are more inclusive.

\section{REFERENCES}

Adkin, L. (2020). Government takeover of post-secondary education. Edmonton, AB: Parkland Institute. URL: https:/l www.parklandinstitute.ca/government_takeover_post_secondary [January, 2021]

Association of Municipalities of Ontario \& Ontario Municipal Social Services Association. (2009). Government makes a difference: Working together towards poverty reduction. Toronto, ON: AMO \& OMSSA. URL: http://www.msdsb.net limages/ADMIN/docs/program_issues/OMSSA-re-Government-Makes-A-Difference.pdf [May, 2020].

Barnetson, B. (2015). Worker safety in Alberta: Trading health for profit. In M. Shrivastava \& L. Stefanick (Eds.), Alberta oil and the decline of democracy in Canada (pp. 225-247). Edmonton, AB: Athabasca University Press. 
Block, S. (2021). Racialized and Indigenous workers are bearing the brunt of pandemic job loss. Ottawa, ON:

Canadian Centre for Policy Alternatives. URL: https://behindthenumbers.ca/2021/01/14/racialized-and-indigenousworkers-pandemic-job-loss/ [March 2021].

Brownsey, K. (2018). Alberta and the great recession: Neoliberalism, conservative government, and public finance. In B.M. Evans \& C. Fanelli (Eds.), The public sector in an age of austerity (pp. 448-470). Montréal, QC: McGillQueen's University Press: URL: https://www.jstor.org/stable/j.ctv39x4vq.6 [November, 2020].

Cabaj, M., Leviten-Reid, E., Vocisano, D., \& Rawlins, M.J. (2016). An example of patch evaluation: Vibrant Communities Canada. In M.Q. Patton, K. McKegg, \& N. Wehipeihana (Eds.), Developmental evaluation exemplars: Principles in practice (pp. 163-191). New York, NY: Guilford Press.

Canada. (2018). Opportunity for all: Canada's first poverty reduction strategy. Ottawa, ON: Employment and Social Development Canada. URL: https://www.canada.ca/en/employment-social-development/programs/poverty-reduction /reports/strategy.html [January, 2021].

City of Edmonton. (2019). Follow-up survey: Edmontonian's attitudes and awareness towards poverty. Leger. URL: https://drive.google.com/file/d/1qCBfunMJGbYoyDy4G0Aqq0bQWWSuS9ZB/view [May, 2021].

Cummins, I. (2018). Poverty, inequality and social work. Bristol, UK: Bristol University Press.

Chang, H-J. (2014). Economics: The user's guide. New York, NY: Bloomsbury Press.

Dixon, J. (2012). On being poor-by-choice: A philosophical critique of neoliberal poverty perspective. Poverty \& Public Policy, 4(2), 1-19.

Dorow, S. (2015). Gendering energy extraction in Fort McMurray. In M. Shrivastava \& L. Stefanick (Eds.), Alberta oil and the decline of democracy in Canada (pp. 275-292). Edmonton, AB: Athabasca University Press.

Edmonton Chamber of Voluntary Organizations. (2016). History of Edmonton's human services sector. Edmonton, AB: Edmonton Chamber of Voluntary Organizations. URL: https://ecvo.ca/wp-content/uploads/2021/01/History-of -Human-Services-Edmonton-Final.pdf [June, 2021].

Edmonton Chamber of Voluntary Organizations. (2021). Transforming the nonprofit community in Edmonton. Edmonton, AB: Edmonton Chamber of Voluntary Organizations. URL: https://ecvo.ca/wp-content/uploads/2021 105/ECVO-Transformation-FINAL-highres.pdf [June, 2021].

Edmonton Community Foundation. [2021]. Vital topic: A primer on income and the cost of living in Edmonton. Edmonton, AB: Edmonton Community Foundation. URL: https://www.ecfoundation.org/wp-content/uploads/FINAL -2021A-primer-on-Income-cost-of-living-in-Edmonton.pdf [July, 2021].

Edmonton Social Planning Council. (2017). A profile of poverty in Edmonton update. Edmonton, AB: Edmonton Social Planning Council. URL: http://ivingwagecanada.ca/files/4515/0096/7057/CityOfEdmontonPovertyProfileUpdate 2017.pdf [July, 2021].

Edmonton Social Planning Council. (2019a). A profile of poverty in Edmonton. Edmonton, AB: Edmonton Social Planning Council. URL: https://edmontonsocialplanning.ca/2019/08/06/a-profile-of-poverty-in-edmonton-may-2019 -update/ [July, 2021].

Edmonton Social Planning Council. (2019b). Living wage: Edmonton 2019. Edmonton, AB: Edmonton Social Planning Council. URL: https://edmontonsocialplanning.ca/living-wage-2019/ [July, 2021].

Edmonton Social Planning Council. (2020a). Tracking the trends. Edmonton, AB: Edmonton Social Planning Council. URL: https://edmontonsocialplanning.ca/wp-content/uploads/2020/11/Tracking-the-Trends-2020-FINALVersion.pdf [July, 2021].

Edmonton Social Planning Council. (2020b). Food (in)security during COVID-19. Edmonton, AB: Edmonton Social Planning Council. URL: https://edmontonsocialplanning.ca/2020/10/28/fact-sheet-food-insecurity-during-covid-19/ [July, 2021].

Emery, J.C., \& Kneebone, R. (2013). Three strikes and you're out? In D.L. Ryan (Ed.), Boom and bust again: Policy challenges for a commodity-based economy (pp. 39-58). Edmonton, AB: University of Alberta Press. 


\section{Kingsley, Morley, Das, Mayan, \& Wallace (2021)}

EndPovertyEdmonton. (2019). A profile of childcare in Edmonton. Edmonton, AB: EndPovertyEdmonton. URL: https:// drive.google.com/file/d/1hw3olMqwflUahqzz_QKHfcn-rkXogk67/view [July, 2021].

EndPovertyEdmonton. (2020). Annual report: Pivot edition. Edmonton, AB: EndPovertyEdmonton. URL: https://www .endpovertyedmonton.ca/2020-annual-report-pivot-edition [July, 2021].

Evans, J. (2015). The paradox of plenty: Ending homelessness in Alberta. In M. Shrivastava \& L. Stefanick (Eds.), Alberta oil and the decline of democracy in Canada (pp. 313-331). Edmonton, AB: Athabasca University Press.

Federation of Canadian Municipalities. (2017). Ending poverty starts locally. Ottawa, ON: Federation for Canadian Municipalities. URL: https://fcm.ca/Documents/issues/Poverty_Reduction_EN.pdf [July, 2021].

Findlay, T., Saulnier, C., \& Stratford, A. (2020). Are you with us? COVID-19 confirms the need to transform Nova Scotia's social safety net. Ottawa, ON: Canadian Centre for Policy Alternatives. URL: https:/www.policyalternatives.ca/sites /defaultfiles/uploads/publications/Nova\%20Scotia\%200ffice/2020/05/Are\%20you\%20with\%20us.pdf [July, 2021].

Flanagan, G. (2015). From gap to chasm: Alberta's increasing income inequality. Edmonton, AB: Parkland Institute. URL: https://www.parklandinstitute.ca/from_gap_to_chasm [November, 2020].

Foster, J., \& Barneston, B. (2015). Exporting oil, importing labour, and weakening democracy: The use of foreign migrant workers in Alberta. In M. Shrivastava \& L. Stefanick (Eds.), Alberta oil and the decline of democracy in Canada (pp. 249-273). Edmonton, AB: Athabasca University Press.

Fraser, J., Mannani, M., \& Stefanick, L. (2015). Petroleum, patriarchy, and power: Women's equality in Canada and Iran. In M. Shrivastava \& L. Stefanick (Eds.), Alberta oil and the decline of democracy in Canada (pp. 171-194). Edmonton, AB: Athabasca University Press.

Goertzen, B. (2020, May 10). Work life: Women's health, unpaid care and COVID-19. Ottawa, ON: Canadian Centre for Policy Alternatives. URL: https://www.policyalternatives.ca/publications/commentary/work-life-women\%E2\%80 \%99s-health-unpaid-care-and-covid-19 [June, 2020]

Graff McRae, R. (2017, September 21). A rising tide doesn't lift all boats: What Census 2016 reveals about income inequality in Alberta. Edmonton, AB: Parkland Institute. URL: https://www.parklandinstitute.ca/a_rising_tide_doesnt _lift_all_boats [February, 2020].

Gross, J. (2008). Community benefits agreements: Definitions, values, and legal enforceability. Journal of Affordable Housing \& Community Development Law, 17(1/2), 35-58.

Hallstrom, L.K. (2018). Rural governmentality in Alberta: A case study of neoliberalism in rural Canada. Revue Gouvernance/Governance Review, 15(2), 27-49.

Hanewich, B. (2019). Liveable income report 2019. A review of strategies and initiatives towards creating liveable incomes for all. Edmonton, $A B$ : EndPovertyEdmonton.

Harrison, T.W. (2015). Petroleum, politics, and the limits of left progressivism in Alberta. In M. Shrivastava \& L. Stefanick (Eds.), Alberta oil and the decline of democracy in Canada (pp. 69-88). Edmonton, AB: Athabasca University Press.

Harrison, T. \& Weber, B. (2015). Neoliberalism and the non-profit social services sector in Alberta. Edmonton, AB: Parkland Institute. URL: https://www.parklandinstitute.ca/neoliberalism_and_the_non_profit_social_services _sector_in_alberta [November, 2020].

Hillel, I. (2020). Holes in the social safety net: Poverty, inequality and social assistance in Canada. Ottawa, ON: Centre for the Study of Living Standards. URL: https://ideas.repec.org/p/sls/resrep/1912.html [January, 2021].

Israel, B.A., Eng, E., Shulz, A.J., \& Parker, E.A. (2013). Introduction to methods for CBPR for health. In B.A. Israel, E. Eng, A.J. Shulz, \& E.A. Parker (Eds.), Methods for community-based participatory research for health. San Francisco, CA: Jossey-Bass.

Jackson, A. (2018). Canada's working poor and the working income tax benefit. Ottawa, ON: Broadbent Institute. URL: https://www.broadbentinstitute.ca/canada_s_working_poor_and_the_working_tax_benefit\#: :text=The\%20WITB \%20is\%20a\%20refundable,move $\% 20$ from $\% 20$ welfare $\% 20$ to\%20work [June, 2020]. 


\section{Kingsley, Morley, Das, Mayan, \& Wallace (2021)}

Keil, R. (2002). "Common-sense” neoliberalism: Progressive conservative urbanism in Toronto, Canada. Oxford, UK: Blackwell.

Lahey, K. (2015). The Alberta disadvantage: Gender, taxation, and income inequality. Edmonton, AB: Parkland Institute. URL: https://www.parklandinstitute.ca/the_alberta_disadvantage [November, 2020].

Larner, W. (2006). Neoliberalism: Policy, ideology, governmentality. In M. De Goede (Ed.), International political economy and Poststructural politics (pp. 199-218). London, UK: Palgrave Macmillan.

Lee, N. (2019). Inclusive growth in cities: A sympathetic critique. Regional Studies, 53(3), 424-434. doi:10.1080/003 43404.2018.1476753

Lefroncois, A. (2015, November 5). Canada's working poor and precarious employment. Living Wage Canada. URL: http://www.livingwagecanada.ca/index.php/blog/canadas-working-poor-and-precarious-employment/ [June, 2020].

Lewchuk, W., Lafleche, M., Dyson, D., Goldring, L., Meisner, A., Procyk, Rosen, D., Shields, J., Viducis, P., \& Vrankulj, S. (2013). It's more than poverty: Employment precarity and household well-being. Hamilton, ON: Poverty and Employment Precarity in Southern Ontario (PEPSO). URL: https://www.unitedwaygt.org/document.doc?id=91 [June, 2020].

Lorde, A. (1984). Sister outsider: Essays and speeches. New York, NY: The Crossing Press.

Lupton, R., Hughes, C., Macdougall, A., Goldwyn-Simpkins, H., \& Hjelmskog, A. (2019). Inclusive growth in greater Manchester 2020 and beyond: Taking stock and looking forward. Manchester, UK: Inclusive Growth Analysis Unit. URL: https://www.mui.manchester.ac.uk/igau/research/reports/ [June, 2020].

Markusoff, J. (2021). This is not what Jason Kenney came back for. Maclean's. URL: https://www.macleans.ca /longforms/jason-kenney-alberta/ [May, 2021].

McCormack, G., \& Gordon, T. (2020). Flagging profitability and the oil frontier: State power, the world market, and settler-colonial capitalism in Canada. Historical Materialism, 28(4), 25-66.

Miller, B. (2007). Modes of governance, modes of resistance: Contesting neoliberalism in Calgary. In H. Leitner, J. Peck, \& E.S. Sheppard (Eds.), Contesting neoliberalism: Urban frontiers (pp. 223-249). London, UK: Guilford Press.

Minkler, M., \& Wallerstein, N. (2008). Community-based participatory research for health: From process to outcomes. San Francisco, CA: Jossey-Bass.

Munro, D. (2020). An inclusive economic monitor for Canada: Discussion paper. Toronto, ON: Brookfield Institute for Innovation \& Entrepreneurship. URL: https://brookfieldinstitute.ca/an-inclusive-innovation-monitor-for-canada-a -discussion- paper/ [November, 2020].

Navarro, V. (1998). Neoliberalism, "globalization," unemployment, inequalities, and the welfare state. International Journal of Health Services, 28(4), 607-682.

Nugent, J. (2017). The right to build the city: Can community benefits agreements bring employment equity to the construction sector? Labour/Le Travail, 80, 81-114.

Parks, V., \& Warren, D. (2009). The politics and practice of economic justice: Community benefits agreements as tactic of the new accountable development movement. Journal of Community Practice, 17(1/2), 88-106.

Patton, M.Q. (2016). State of the art and practice of developmental evaluation: Answers to common and recurring questions. In M.Q. Patton, K. McKegg, \& N. Wehipeihana (Eds.), Developmental evaluation exemplars: Principles in practice (pp. 1-24). New York, NY: Guilford Press.

Preston, J. (2017). Racial extractivism and white settler colonialism: An examination of the Canadian Tar Sands megaprojects. Cultural Studies, 31(2-3), 353-375.

Raphael, D. (2020). Poverty in Canada: Implications for health and quality of life. Toronto, ON: Canadian Scholars.

Raworth, K. (2017). Doughnut economics: Seven ways to think like a 21st century economist. White River Junction, VT: Chelsea Green Publishing.

Riches, G. (2002). Food banks and food security: Welfare reform, human rights and social policy. Lessons from Canada? Social Policy \& Administration, 36(6), 648-663. 


\section{Kingsley, Morley, Das, Mayan, \& Wallace (2021)}

Russek, H., Thornton, J., \& Elias, D. (2021). Yesterday's gone: Exploring the future of Canada's labour market in a post-COVID world. Toronto, ON: Brookfield Institute. URL: https://brookfieldinstitute.ca/future-of-work-in-post-covid -canada/ [May, 2021].

Scherer, J., Mills, D., \& Sloan McCulloch, L. (2019). Power play: Professional hockey and the politics of urban development. Edmonton, AB: University of Alberta Press.

Shrivastava, (2015) Conclusion: Of democracy and its deficits: Surviving neoliberalism in oil-exporting countries. In M. Shrivastava \& L. Stefanick (Eds.), Alberta oil and the decline of democracy in Canada (pp. 391-410). Edmonton, AB: Athabasca University Press.

Shrivastava, M. (2018). Perils of petroculture in a neoliberal resource economy. In J. Brodie (Ed.), Contemporary inequalities and social justice in Canada (pp. 127-141). Toronto, ON: University of Toronto Press.

Shrivastava, M., \& Stefanick, L. (2015). Introduction: Framing the debate on democracy and governance in an oilexporting economy. In M. Shrivastava \& L. Stefanick (Eds.), Alberta oil and the decline of democracy in Canada (pp. 3-28). Edmonton, AB: Athabasca University Press.

Sousa, J., \& Alberio, M (2020). Coming out of a crisis: What next? Canadian Journal of Nonprofit and Social Economy Research, 11(1), 3-6.

Spade, D (2015). Normal life: Administrative violence, critical trans politics, and the limits of law. Durham, NC: Duke University Press.

Stanford, J. (2020). 10 ways the COVID-19 pandemic must change work for good. Centre for Future of Work. URL: https://centreforfuturework.ca/wp-content/uploads/2020/06/10Ways_work_must_change.pdf [May, 2021].

Statistics Canada. (2016). Market basket measure. Ottawa, ON: Statistics Canada. URL: https://www12.statcan.gc.ca /census-recensement/2016/ref/dict/pop165-eng.cfm [November, 2020].

Statistics Canada. (2018). Low income statistics by age, sex and economic family type. Ottawa, ON: Statistics Canada. URL: https://www150.statcan.gc.ca/t1/tbl1/en/tv.action?pid=1110013501\&pickMembers\%5B0\%5D=1.20 \&cubeTimeFrame.startYear=2017\&cubeTimeFrame.endYear=2018\&referencePeriods=20170101\%2C20180101 [November, 2020].

Statistics Canada. (2020a, February 24). Canadian income survey, 2018. Ottawa, ON: Statistics Canada. URL: https:// www150.statcan.gc.ca/n1/daily-quotidien/200224/dq200224a-eng.htm [May, 2020].

Statistics Canada. (2020b, April 9). Labour force survey, March 2020. Ottawa, ON: Statistics Canada. URL: https:// www150.statcan.gc.ca/n1/daily-quotidien/200409/dq200409a-eng.htm [May, 2020].

Statistics Canada. (2020c, May 8). Labour force survey, April 2020. Ottawa, ON: Statistics Canada. URL: https://www 150.statcan.gc.ca/n1/daily-quotidien/200508/dq200508a-eng.htm [June 2020].

Statistics Canada. (2020d, June 5). Labour force survey, May 2020. Ottawa, ON: Statistics Canada. URL: https:// www150.statcan.gc.ca/n1/daily-quotidien/200605/dq200605a-eng.htm [August, 2020].

Statistics Canada. (2020e, August 7). Labour force survey, July 2020. Ottawa, ON: Statistics Canada. URL: https:// www150.statcan.gc.ca/n1/daily-quotidien/200807/dq200807a-eng.htm [November, 2020].

Statistics Canada. (2021, Feb 5). Labour force characteristics by province. Ottawa, ON: Statistics Canada. URL: https: //www150.statcan.gc.ca/n1/daily-quotidien/210205/t003a-eng.htm [May, 2021].

Thobani, S. (2007). Exalted subjects: Studies in the making of race and nation in Canada. Toronto, ON: University of Toronto Press.

Tomiak, J. (2017). Contesting the settler city: Indigenous self-determination, new urban reserves, and the neoliberalization of colonialism. Antipode, 49(4), 928-945.

Utting, P. (2015). Social and solidarity economy: Beyond the fringe. London, UK: Zed Books.

van Barneveld, K., Quinlan, M., Kriesler, P., Junor, A., Baum, F., Chowdhury, A., Junankar, P.N., Clibborn, S., Flanagan, F., Wright, C.F., Friel, S., Halvie, J., \& Rainnie, A. (2020). The COVID-19 pandemic: Lessons on building more equal and sustainable societies. The Economic and Labour Relations Review, 31(2), 133-157. doi:10.1177/1035304620927107 
van Osch, T. (2013). Towards a caring economic approach. URL: https://oqconsulting.eu/wp-content/uploads/2020/04 /The-Economy-of-Care.pdf [October, 2019].

Wacquant, L. (2009). Punishing the poor: The neoliberal government of social insecurity. Durham, NC: Duke University Press.

\section{ABOUT THE AUTHORS / LES AUTEURS}

Bethan Kingsley is a Community-Based Researcher and Evaluator who works at the Community-University Partnership for the Study of Children, Youth and Families (CUP) and the Women and Children's Health Research Institute (WCHRI) at the University of Alberta. Email: bkingsle@ualberta.ca

Kirstyn Morley is a Research Coordinator with the Community-University Partnership for the Study of Children, Youth, and Families at the University of Alberta. She has supported a diversity of research and evaluation projects related to poverty and child development, working from a community-based approach. She holds a Master of Education. Email: krmorley@ualberta.ca

Surma Das is a Community-Engaged Researcher and a Public Policy Advocate with more than fifteen years of professional experience on a range of social policy issues. She holds a PhD in Political Science and International Development Studies from the University of Guelph, Ontario, Canada. Email: surma@ualberta.ca

Maria Mayan is a Professor in the School of Public Health and Associate Director of the Community-University Partnership. Her work lies at the intersection of government, non-profit, lived experience, and industry to tackle complex health and social issues and she commits to initiatives over the long-term and has embedded her research program in EndPovertyEdmonton. Email: mmayan@ualberta.ca

Emma Wallace is a Research Assistant at the Community-University Partnership at the University of Alberta. In this role, she conducts poverty-related research. Emma is committed to using community-based participatory approaches to her research and evaluation work and aims to ensure an equity-lens is also at the forefront of her projects. Email: emma lynn@ualberta.ca 